\title{
Grygorak $M$. \\ COMPARISON OF ECONOMIC INDICATORS OF USING THE UKRAINIAN LOGISTICS POTENTIAL
}

Узагальнено сутність та визначення логістичного потенціалу начіональної економіки, визначено ключові показники його ефективного використання. Запропоновано сукупність економічних індикаторів, що визначають рівень використання потенціалу логістики на макрорівні. Проведено аналіз впливу економічних індикаторів на конкурентоздатність та ефективність національноі економіки з точки зору ї геоекономічного виміру. Розраховано очіночні значення нащіональних логістикичних витрат та розроблено пропозиції з удосконалення логістичної системи України у відповідності до стратегічних пріоритетів національної економіки.

Ключові слова: національна логістична система, логістичний потенціал національної економіки, ринок логістичних послуг.

\section{Introduction}

In the search for optimal ways of Ukraine's economic recovery from the crisis, exacerbated by military actions in the east of the country, the effective use of the existing resource potential, in particular, the logistics one, becomes extremely topical. The processes of globalization, internationalization and transnationalization of the world economy contributed to the growth of the role of logistics as an effective tool for increasing the efficiency and competitiveness of enterprises in the markets of goods and services, and also led to the formation of international transport corridors, global and regional supply chains. Logistics has an increasing influence on the formation of the structure of the national economy, determining its profile, which is manifested in the growth of the contribution of logistics services in the GDP structure, the growth in the number of employed workers, the complication of logistics interactions and the attraction of significant investment funds in the development of transport and logistics infrastructure. It is obvious that a change in economic models leads to the creation of new mechanisms and adaptation institutions that can neutralize crisis phenomena and eliminate inconsistencies between new business processes and old infrastructures in a transformed innovation environment.

Because Ukraine has an advantageous geographical location at the crossroads of many pan-European transport corridors, has one of the world's largest railways density, is a maritime and aviation state, has significant transit and tourism potential, that to maximize the use of these potential opportunities, it is necessary to consolidate the efforts of business and government for selection and implementation of infrastructure projects that will stimulate economic growth. To effectively use limited resources and take into account geo-economic factors, the problem of assessing the quality and prospects of the development of Ukraine's logistics potential in the context of European integration becomes particularly important. Many foreign experts believe that Ukraine has a huge logistics potential, which is estimated at $\$ 100$ billion. However, ineffective state management, underestimation of the role and mechanisms of logistics by domestic state institutions, insufficient level of competence of logistics personnel at all levels of management have led to a systemic non-use of this potential, and the growing competitive positions of neighboring countries in the development of logistics infrastructure on the border with Ukraine mitigate the image of our state as transit.

\section{The object of research and its technological audit}

The tasks of economic growth set by the Ukrainian government require not only increasing the competitiveness of domestic goods in the international markets from the point of view of their price, but also ensuring effective interaction of domestic enterprises with foreign business partners in global and regional supply chains, creating conditions for the seamless movement of commodity flows in the network of international logistic corridors, develop cross-border cooperation and seek opportunities to obtain synergetic effect increasing the added customer value and reduce total costs of participants of network cooperation, global partnerships, alliances and geo-economic alliances. An adequate assessment of the capabilities of the country's logistics system stimulates decisions on investing in infrastructure at both the national and regional levels in order to ensure their sustainable social and economic development.

The object of research is methodical approaches to assessing the level of use of the logistic potential of the national economy in terms of its competitiveness and effective use of available resources.

General trends in development of the world economy and the experience of the world's leading countries show that logistics has become an important national resource, an instrument for increasing the efficiency of the economy in the country, as well as a separate branch of the economy, and has a powerful export potential. The total volume of the world logistics market is almost 4 trillion US dollars and is projected to grow by $6.5 \%$ to 2021 [1, 2]. In this regard, countries are developing national strategies for development of logistics and conducting research on the 
feasibility of implementing the existing logistics capacity in accordance with the strategic priorities of the national economy [3-5]. The experience of Germany, Finland, the Netherlands, China, Singapore, and Malaysia shows that due to effective logistics it is possible to significantly improve the efficiency of doing business in the country, as well as the economic efficiency and competitiveness of the national economy [6]. To carry out comparative analysis and benchmarking of national logistics systems, the World Bank's logistics performance index is an effective tool, enabling countries to increase the effectiveness of logistics activities, to define economic policies and visually compare the results of their country and similar countries to move goods between countries and establish links with global supply chains [7]. The act of studying foreign experience in the development of national logistics systems and the successful combination of economic interests from the point of view of developing domestic production and attracting domestic producers to global supply chains will enable to realize a powerful logistical potential and to determine the priorities for attracting significant investment funds for development of the logistics infrastructure.

\section{The aim and objectives of research}

The aim of research is determination of the features and methods for assessing the logistical potential of Ukraine, taking into account the geo-economic factors and priorities for development of the national economy.

To achieve this aim, the following tasks are defined:

1. To formulate the definition of the logistics potential of the national economy.

2. To prove the interrelation of the quality of the country's logistics system with the competitiveness and efficiency of the national economy, to carry out a rating and statistical analysis of utilization level of the logistic potential of Ukraine.

3. To analyze the efficiency of using the logistics potential of Ukraine from the point of view of the total logistics costs and the cost of the logistics component of the national economy.

\section{Research of existing solutions of the problem}

The problems of the economic potential in general and of its components for different economic systems are under the constant scientific view of both domestic and foreign scientists. The most researched, in our opinion, is the essence, structure and features of realizing the potential of the enterprise. At the same time, a statistically significant relationship between the productive power of the potential of a particular economic entity and the infrastructure characteristics of the region and the national economy is evidence of an increasing number of scientific papers [8].

In the opinion of the majority of scientists, so far the concept of «logistic potential» is significantly expanded and has both quantitative and qualitative characteristics of logistical processes at various levels of management. World researchers of macroeconomic logistic systems have defined the practical potential of logistics as its ability to influence the value of logistics costs in the aggregate value of goods and services [9, 10]. In work [11], attention is paid to the fact that the logistic potential makes it possible to realize the strategic goals of the organization, including the state. Belarusian scientists have developed a methodical approach to assessing the state's logistical potential in the context of the globalization of the economy [12]. The economic essence of the logistic potential of supply chains is investigated in [13].

Among domestic researchers, most publications are devoted to the study of the logistics potential of an enterprise or region [14-17]. Separate aspects of the logistical activity of the national economy and the use of its logistical potential are reflected in the works [18-20]. However, many problematic provisions and methodological approaches are left without attention of domestic researchers and require further study.

\section{Methods of research}

In scientific works on the problems of formation and development of both the potential in general and the logistical potential in particular, the measurement of the magnitude of the available potential and the level of its use has not been sufficiently developed. In general, proponents of the resource approach propose to use expert, point, rating and index methods, effective - statistical methods.

Most often, when assessing the logistic potential of Ukraine, the authors refer to international indices and ratings, in particular, global competitiveness, ease of doing business, human development, economic freedom, trade facilitation, tourism and tourism competitiveness, etc. Among these international systems for assessing and positioning national economics, the Logistics Performance Index (LPI) has particular importance. It was developed by the World Bank jointly with the Turku University (Finland) for assessing the level of development of the logistics services market. The proposed method involves conducting a study every two years with the participation of more than 160 countries. According to a specially developed system of indicators, experts with experience in the field of logistics are interviewed. They put the grades on a 5-point scale $(1-$ the minimum value, 5 - the maximum value of the indicator). In a single format, a database is created for each country on a certain level of efficiency of the work of customs bodies, the quality of infrastructure and logistics services, the competence of personnel and the timing parameters of individual logistics processes and procedures. The main drawback of this approach is the subjectivity of expert assessments and the small size of the assessment scale that significantly affects the sharp changes in positions in the rating and underestimates the real variation in the variations of individual indicators for different countries.

To assess the state of logistics at the level of the national economy, the method of data collection based on the survey of enterprises from different industries is often used, it allows to determine generalized assessments of the state of the logistics market in general and the level of utilization of the country's logistics potential. This method is often used in Germany, Finland, Switzerland, Thailand, Indonesia, Malaysia, etc. [3-6]. In some countries, more detailed studies of the services market of 3PL-operators are conducted and on the basis of it make conclusions about the use of the country's logistical potential $[2,21]$.

The most common method is the collection and processing of statistical data that are carried out by national statistical bodies or international organizations. This approach allows 
to determine the specific weight of logistical costs in the country's GDP structure and on a precise basis to determine the absolute value. Total logistics costs include the costs of all industries and all types of economic activities for the implementation of logistics processes over a certain period of time and is the measure of the effectiveness of logistics activities. Let's note that the value of logistics costs was one of the indicators of the LPI rating, but since the methodology for determining the proportion of logistics costs in the GDP structure of different countries differed significantly, in 2012 this indicator was removed from the assessment system.

In countries that are leaders of the global logistics efficiency rating, more sophisticated methods are used to assess the state of the logistics sector. In particular, in the UK, 52 indicators are used in dynamics over 4 years, which are grouped according to the following characteristics: road and transport indicators, safety, efficiency, transport flow, economic indicators [19].

Belarusian scientists consider linear characteristics of infrastructure (density and length of roads, etc.), the point characteristics of infrastructure (number of airports, water ports, transport terminals, etc.) to the most important and simple indicators of LP estimation, the key characteristics of the infrastructure (size of warehouses, the number of logistics centers, distribution centers, etc.) [12]. In work [17], 5 components for the calculation of the index of the region's logistics potential are proposed: geographic, socioeconomic, transport, infrastructure and institutional.

Let's note that these approaches have a number of shortcomings:

- estimation of commodity turnover is based on cost indicators that contain the inflationary component, which does not allow to correctly estimate its dynamics;

- quantitative estimates of the volume indicators of the infrastructure development do not reflect its quality and efficiency of use;

- the majority of macroeconomic indicators do not reflect the development of new key business competencies, including in logistics;

- the lack of methods for assessing the managerial effectiveness of the functioning of the national logistics system leads to strategic and tactical errors in logistics management.

Given the existing methodological difficulties in determining the level of use of the logistical potential of the national economy, let's believe that it is most expedient to focus on a combination of expert and statistical assessments. This approach will allow to identify key indicators of the effectiveness and efficiency of logistics activities and, accordingly, they can be used as economic indicators.

\section{Research results}

The generalization of world experience shows that the logistic system of the national economy should allow all participants of the commodity movement to realize their economic interests and the goals of logistic activity, oriented to:

- effective logistical operations and streamlining processes management of streaming processes in logistics systems of various levels;

- flexibility and ability to respond quickly to various fluctuations in consumer and market demand,

- implementation of monitoring and control of the work of all participants in regional and global supply chains.
From this position it is possible to determine the logistical potential of the country as the ability of the logistic system to achieve its strategic goals in the most efficient way in terms of time, quality and expenditure, taking into account the influence of factors of its internal and external environment. Summarizing the theoretical positions of different scientists on the definition of the economic essence and the conceptual model of the logistic potential, we propose an information vision in the form of a four-dimensional model with the system of coordinates «resources-abilities-control system-competence», where the resource plane reveals the phenomenon of transforming capabilities into abilities, and abilities for their disclosure, fixing and updating with the help of training are transformed into competence (Fig. 1). The implementation of a set of such opportunities occurs in the context of business processes and self-organization processes and contributes to the creation of value for stakeholders. The satisfaction degree of the requests of various interested parties from the result of the transformation of resources and the success of enterprises as a whole depends not only on the availability of resources, but also on knowledge and skills to unite them into unified technological and managerial processes, that is, from intellectual and human potentials.

The understanding of the logistical potential of the national economy presented in Fig. 1 reflects not only the availability of resources for the logistic activities of enterprises and state institutions, the formation and development of a market for logistics services, but also the availability of key personal and business competencies. Let's note that the term «key business competencies» means the integrated set of competences (interrelated knowledge, skills and abilities) of logistics staff, as well as the latest technologies and competitive advantages (intellectual capital) that form the ability of the management system of the national logistics system to effectively manage the logistics processes and functions, as well as to define a logistic development strategy and to promote qualitative changes in the macroeconomic system.

As shown in [19], the basis for formation of the logistic potential lies in the justification of the size of the resources to ensure the required quality level of the logistics service. At the stage of determining optimal resources, material, information, financial flows are transformed into a necessary and sufficient logistical service by the appropriate information and financial support. Achievement of the optimal level of realization of the logistics potential is possible as a result of the synthesis of its constituent parts - resources, capabilities, competencies and operating conditions of micro, meso- and macro-logistic systems. More efficient use of the existing potential should contribute to increasing the competitiveness of the national economy, the quality of logistics services and reducing added value in regional and national supply chains. In the context of international economic activity, the realization of the country's logistics potential should contribute to the creation of competitive advantages of Ukrainian goods on world markets by maximizing consumer value and reducing the costs of commodity traffic. World experience shows that countries with a high level of logistics efficiency are able to provide enterprises with access to international markets through reliable supply chains. Countries with low logistics efficiency have high logistical costs, adversely affects the competitiveness of the national economy. 


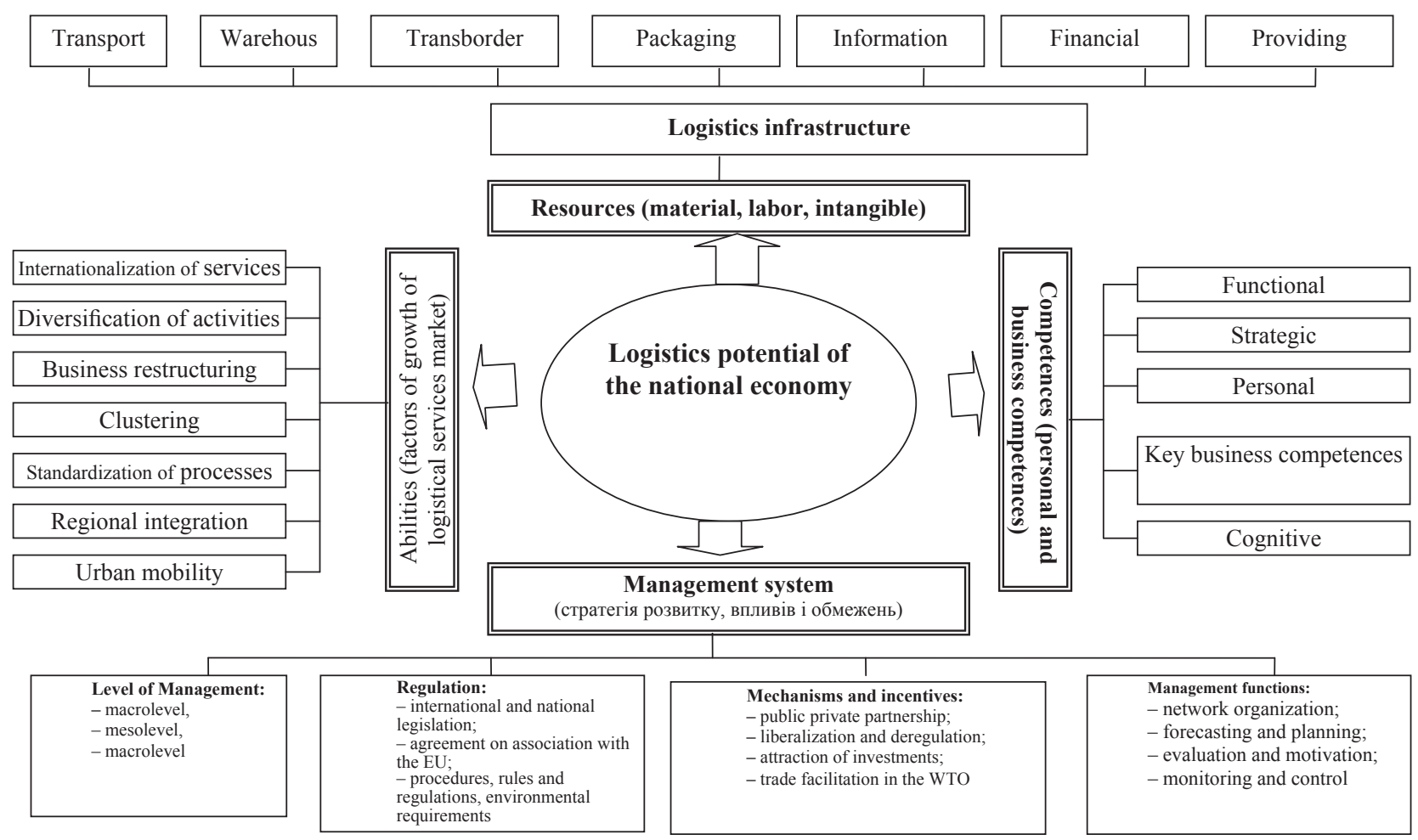

Fig. 1. Conceptual scheme of the concept of «logistics potential of the national economy"

In order to characterize the general condition of logistics in Ukraine, as well as assessing the level of use of logistics potential, let's use the data of the global competitiveness ratings and logistical effectiveness of the World Bank. According to the report «Global Competitiveness Index 2016-2017» Ukraine lost 6 positions in comparison with the previous year and took 85th place among 138 countries of the world [22]. Among the main reasons for this situation experts call deterioration of the infra- structure of roads, rail, sea and air transport. According to the road surface quality of Ukraine takes 134th place among 138 countries (Table 1).

The positions of Ukraine also deteriorate in the global rating of logistics efficiency (Table 2). According to the index of logistics efficiency in 2016, Ukraine ranked 80th in the rating, although in 2014, when there was a noticeable deterioration in the economic situation, Ukraine occupied 61st line [7].

Place of Ukraine in the global rating of Ukraine's competitiveness in the transport infrastructure quality

Table 1

\begin{tabular}{|l|c|c|c|}
\hline \multirow{2}{*}{ Rating indicators } & \multicolumn{2}{|c|}{ Years of rating and number of participating countries } \\
\cline { 2 - 4 } & $2014-2015$ (144 countires) & $2015-2016$ (140 countires) & 2016-2017 (138 countires) \\
\hline Global competitiveness index & 76 & 79 & 85 \\
\hline - transport infrastructure & 88 & 91 & 91 \\
\hline - quality of the entire infrastructure & 75 & 82 & 88 \\
\hline - road quality & 139 & 132 & 34 \\
\hline - railway infrastructure quality & 25 & 28 & 96 \\
\hline - port infrastructure quality & 107 & 108 & 103 \\
\hline - air transport infrastructure quality & 99 & 97 & \\
\hline
\end{tabular}

Table 2

Dynamics of indicators of Ukraine's logistics efficiency for the period 2007-2016

\begin{tabular}{|l|c|c|c|c|c|c|c|c|c|c|}
\hline \multirow{2}{*}{ Indicators } & \multicolumn{2}{c|}{2007} & \multicolumn{2}{c|}{2010} & \multicolumn{2}{c|}{2012} & \multicolumn{2}{c|}{2014} & \multicolumn{2}{c|}{2016} \\
\cline { 2 - 13 } & Place & Points & Place & Points & Place & Points & Place & Points & Place & Points \\
\hline Integral index & 73 & 2.55 & 102 & 2.57 & 66 & 2.85 & 61 & 2.98 & 80 & 2.74 \\
\hline Quality of custams procedures & 97 & 2.22 & 135 & 2.02 & 88 & 2.41 & 69 & 2.69 & 116 & 2.3 \\
\hline Infrastructure & 74 & 2.35 & 79 & 2.44 & 70 & 2.69 & 71 & 2.65 & 84 & 2.49 \\
\hline International sending & 83 & 2.53 & 84 & 2.79 & 83 & 2.72 & 67 & 2.95 & 95 & 2.59 \\
\hline Competence & 90 & 2.41 & 77 & 2.59 & 61 & 2.85 & 72 & 2.84 & 95 & 2.55 \\
\hline Control & 81 & 2.53 & 112 & 2.49 & 50 & 3.15 & 45 & 3.2 & 61 & 2.96 \\
\hline Timeliness & 55 & 3.31 & 114 & 3.06 & 68 & 3.31 & 52 & 3.51 & 54 & 3.51 \\
\hline
\end{tabular}


From 2007 to 2016, the dynamics of the LPI indicator for Ukraine was as follows: the largest indicator was shown by 2014 (61th place, 2.98 points), the smallest 2010 (102th place, 2.57 points, although in 2007 the country took 73 th place with a lower total point of 2.55). The worst indicator among all the estimated characteristics of Ukraine was demonstrated by customs processing of goods from 2007 to 2016, excluding 2014.

Fig. 2 graphically presents a comparative analysis of Ukraine's indicators with the country-leader of the ranking Germany (1st place) and neighboring Poland (33th place). If the points are considered for each characteristic separately, Ukraine is worse than the estimated for customs processing of goods (2.30 points against 4.12 in Germany and 3.27 in Poland), this is the 116th place in the list, according to the rating by a separate characteristic. It is better for Ukraine to assess the timeliness of delivery of goods to destinations (3.51 points against 4.45 in Germany and 3.8 in Poland), this is the 54th place in the list.

We are forced to state that under the influence of the economic crisis, geopolitical factors and military actions in the east of the country during the last few years there has been a stagnation and even degradation of the logistics services market, accompanied by a decrease in cargo transportation volumes, an increase in the vacancy of warehouse facilities, dumping of service prices, logistical activity, actual loss of transit flows.

The decrease in demand from the main consumers of logistics services was due to a significant reduction in the volume of industrial production, imports of goods and trade. The decrease in the import of goods to Ukraine and the active stimulation of exports led to significant changes in the geography of supplies. As a result, we received a new configuration of transport routes and increased costs.

The drop in effective demand, the reduction in consumer activity in the regions caused a decrease in freight traffic within the country and led to increased competition among modes of transport, an increase in the share of road transport, negatively affected the state of roads and road infrastructure.

The relationship between the results of logistics activities at the macro level and national and global competitiveness is indicated by the statistical data given in Table 3 . For comparison, we have chosen the leading economies of the world economy - the USA, China, Germany, the country that has the most experience of researching the logistic potential - Finland, as well as the countries bordering with Ukraine. The World Bank's World Development Indicators database is a source of information about the GDP of countries.

So, the data of international ratings of global competitiveness and logistic efficiency demonstrate the interrelation of their results with the state and quality of logistics in the country. Those countries that consider logistics as an industry take active measures to reduce logistics costs in relation to the gross domestic product. In most developed countries that are in the TOP-20 on the above ratings, logistics costs range from $8 \%$ to $10 \%$. Countries that are actively developing (China, India, Turkey, Kazakhstan), pay special attention to raising funds for the development of logistics infrastructure and simplification of international trade procedures, which contributes to the reduction of added value in logistics.

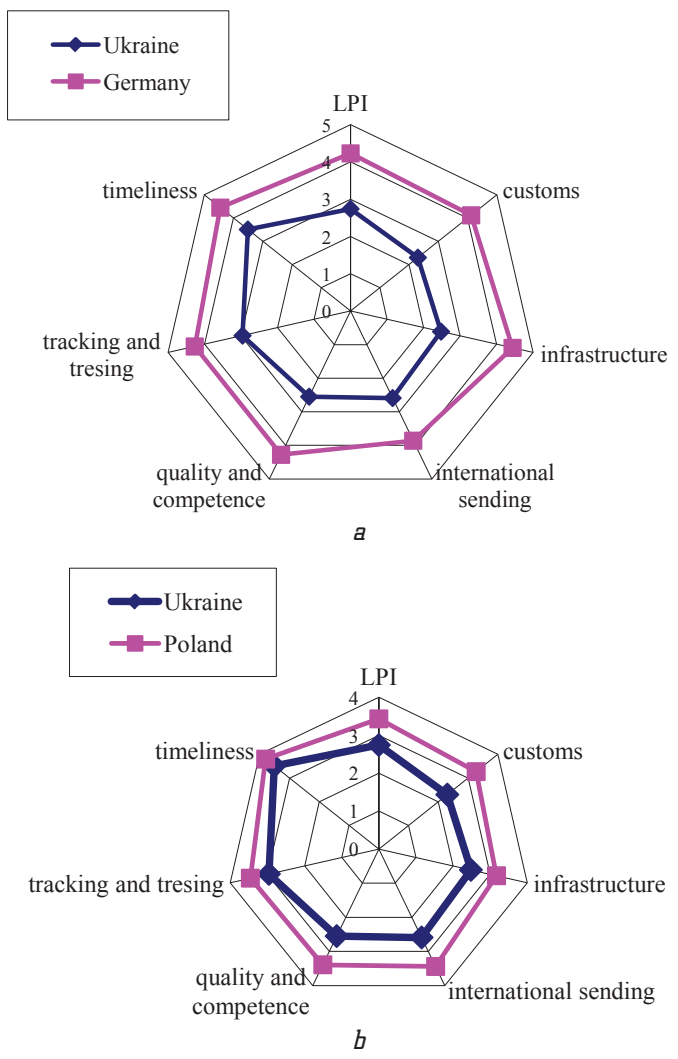

Fig. 2. Comparison of logistic performance indicators: $a$ - indicators of Ukraine and Germany; $b$ - indicators of Ukraine and Poland

Tahle 3

Comparative analysis of Ukraine's position in world ratings in terms of global competitiveness and logistics efficiency

\begin{tabular}{|c|c|c|c|c|c|c|}
\hline Country & $\begin{array}{c}\text { GDP, } \\
\text { bln. \$ }\end{array}$ & $\begin{array}{c}\text { IMD Global } \\
\text { Competitive- } \\
\text { ness Rating }\end{array}$ & $\begin{array}{c}\text { IMD Global } \\
\text { Competitive- } \\
\text { ness Index }\end{array}$ & $\begin{array}{c}\text { Logistics } \\
\text { Performance } \\
\text { Rating (LPI) }\end{array}$ & $\begin{array}{c}\text { Logistics } \\
\text { Perfor- } \\
\text { mance } \\
\text { Index (LPI) }\end{array}$ & $\begin{array}{c}\text { Specific weight } \\
\text { of the logistics } \\
\text { industry in the GDP } \\
\text { structure, \% }\end{array}$ \\
\hline U5A & 17947.0 & 3 & 5.7 & 10 & 3.99 & 8.2 \\
\hline China & 10982.8 & 28 & 5 & 27 & 3.66 & 18 \\
\hline Germany & 3357.6 & 5 & 5.6 & 1 & 4.23 & 8.8 \\
\hline Finland & 229.7 & 10 & 5.4 & 15 & 3.92 & 11.4 \\
\hline Poland & 474.9 & 36 & 33 & 33 & 3.43 & 9.3 \\
\hline Bulgaria & 49.0 & 56 & 4.4 & 72 & 2.58 & 14 \\
\hline Russia & 1324.7 & 43 & 4.5 & 99 & 2.57 & 19 \\
\hline Turkey & 733.6 & 55 & 4.4 & 34 & 3.42 & 10.7 \\
\hline India & 2090.7 & 39 & 4.5 & 35 & 3.42 & 13 \\
\hline Kazakhstan & 217.9 & 53 & 4.41 & 77 & 2.75 & 16 \\
\hline Ukraine & 90.5 & 85 & 4 & 80 & 2.74 & - \\
\hline
\end{tabular}

Note: Data for 2016 based on $[7,21,22]$ 
We want to draw attention to yet another scientific and practical problem. In many countries of the world, research is being done to calculate the indicator of the total logistics costs of the national economy. For example, in the US, Finland, Germany, dynamics and structure of logistics costs for decades are analyzed [23-27]. However, in Ukraine such studies are not conducted, there is no statistical basis for their identification at the national level, and there is no methodology for calculating them. In order to be able to correctly compare the absolute value of logistics costs and their share in the structure of national GDP, it is necessary to standardize the components of logistics costs and the methods for their measuring. It is extremely important to formulate a generally accepted system of logistic accounting and standardize those components of costs that must be included in the total cost of logistics, as well as the process of calculating the cost.

According to the classification of economic activities in Ukraine, a separate sector of the economy is group $\mathrm{H}$, which includes transport, warehouse, courier and postal services. Total costs for this group take into account only the cost of transport and storage services provided on an outsourcing basis. They do not reflect the logistic component of the produced national product. At the same time, the allocation of logistics costs as a percentage of GDP gives an idea not only about the size of the logistics industry through the prism of selling logistics services in the country, but also about the productivity and efficiency of the management system.

In [28], an original method for calculating logistic costs is proposed, taking into account official statistics on the specific weight of logistics costs in the GDP structure as an added value of specialized logistics companies and allows them to be adjusted taking into account the sectoral structure of the national economy. The authors of the study note that there are industries that do not directly consume logistics resources, for example, such as finance and insurance, information technology, etc. Although these activities indirectly require logistic services, they are already reflected in other industries. Therefore, the scientists propose to calculate the MALC (Macro logistics cost), which takes into account the volume of production with high and low added value. Then the share of logistics costs (WLC (weight of logistics costs)) in the structure of the country's GDP is calculated by the formula:

$$
W L C=\frac{M A L C}{H_{1} H_{2}+L_{1} H_{2}},
$$

where $H_{1}$ - the volume of production of products with high added value (industries, construction, service); $L_{1}-$ the volume of production with low added value (extractive industries, agriculture, fishing and forestry); $\mathrm{H}_{2}$ - products having direct contact with logistic activity. According to the proposed model, one can prove the assumption that countries with a large volume of industrial production have a greater demand for logistics activities and then the share of logistics costs in the GDP structure will be greater.

Table 4 contains the initial data for the calculation of logistics costs using the MALC method, and Fig. 3 graphically shows the range of calculated values.

Analysis of the industrial structure of Ukraine's GDP shows, first, the raw-material orientation of the economy, the trends in the increase in exports of agricultural products and minerals, and secondly, the decrease in the share of industrial production, in 2016 amounted to only $14.5 \%$. A sharp decline in industrial production led to a decrease in cargo flows, in the conditions of the economic crisis, often led to the dumping of prices for logistics services.

Fig. 3 shows the dynamics of the share of transport, warehouse, postal and courier services in the GDP structure. Taking into account that the volumes of cargo transportation by various modes of transport tended to decrease, a small increase in the volume of production of this group in the cost dimension is explained by inflation.

Fig. 3 shows that the share of transport, warehouse, postal and courier services in the structure of Ukraine's GDP declined annually until 2014 inclusive and grew in 2015. The greatest demand for transport services was recorded in agriculture, manufacturing and mining. The structure of exports is dominated by grain, ferrous metals and semi-finished products. Transportation costs range from $0.7 \%$ to $12.4 \%$ in the total cost structure of Ukrainian producers. In foreign trade, transport accounts for $12.1 \%$ of export and $5.3 \%$ of import costs. Experts believe that the logistics cost of transporting grain from the producer to the seaport is $40 \%$ higher than in Germany or France.

Table 4

Statistical data of the structure of Ukraine's gross domestic product by types of economic activities for 2010-2016 (mln. UAH)

\begin{tabular}{|l|c|c|c|c|c|c|c|}
\hline \multicolumn{1}{|c|}{ Industry } & 2010 & 2011 & 2012 & 2013 & 2014 & 2015 & 2016 \\
\hline Agriculture, forestry and fishing & 80385 & 106555 & 109785 & 128738 & 161145 & 239806 & 267863 \\
\hline Extractive industry and quarrying & 63436 & 84872 & 81660 & 81259 & 79120 & 95141 & 111791 \\
\hline industry & 142700 & 154675 & 173912 & 165055 & 194050 & 236692 & 242373 \\
\hline Supply of electricity, gas & 30295 & 39994 & 43491 & 42366 & 44836 & 53385 & 54453 \\
\hline Water supply, sewerage, waste & 7736 & 7302 & 6625 & 6573 & 7236 & 7924 & 8082 \\
\hline Building & 35366 & 39575 & 39049 & 36902 & 36876 & 38928 & 39707 \\
\hline Wholesale and retail trade & 154994 & 193357 & 200763 & 212090 & 233702 & 273989 & 279469 \\
\hline Transport, warehousing, postal and courier activities & 83027 & 103179 & 98859 & 104483 & 100889 & 134978 & 157278 \\
\hline Gross domestic product & 1079346 & 1299991 & 1404669 & 1465198 & 1586915 & 1988544 & 2383000 \\
\hline
\end{tabular}




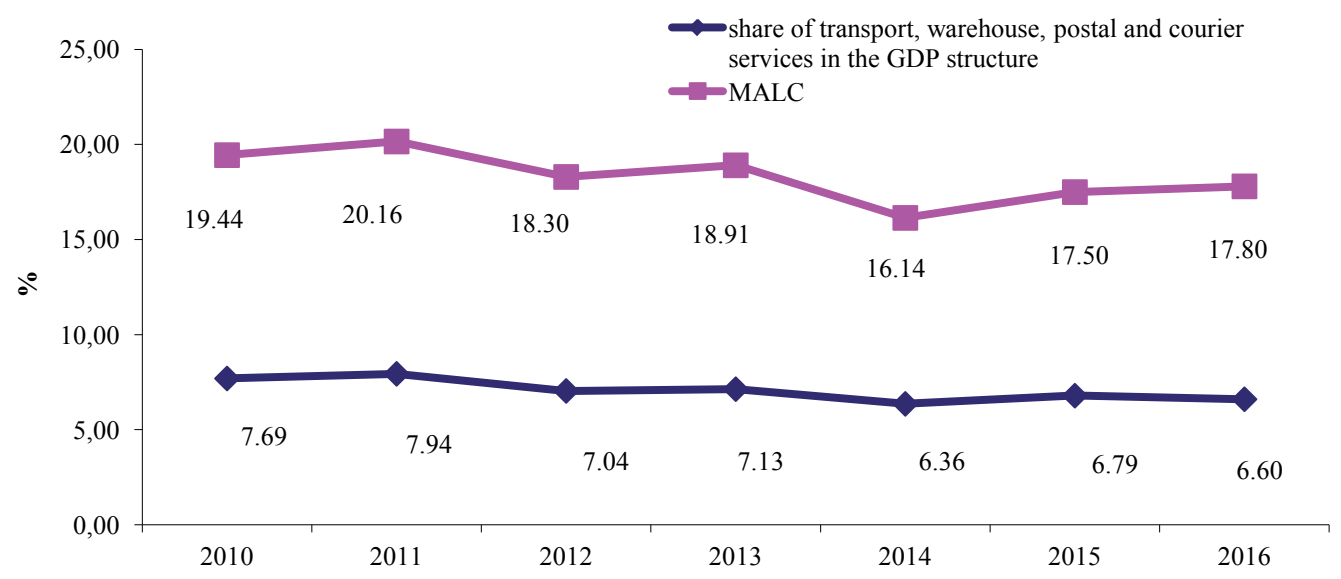

Fig. 3. Dynamics of the estimated indicators of the logistic component in the GDP structure

The calculated MALC indicator allows to estimate the value of logistics costs in the structure of Ukraine's GDP and graphically represent their dynamics. From a macroeconomic point of view, logistics costs can be divided into four categories: transportation costs, inventory costs (inventory maintenance), administrative costs and infrastructure costs. The calculations show that transport costs are less than half of the logistics costs (without taking into account the insourcing). This means that the national economy has significant efficiency losses for large inventory costs, administrative and customs barriers, price barriers, information costs, costs associated with the use of various currencies, and the like.

Comparison of the state and development trends of the Ukrainian market of logistics services to the results of global market research shows that we are going through the same stages of development, but much faster. We have the opportunity to focus on the best world experience, best cases and practices, invest only in quality facilities. The main thing is that the Ukrainian business and domestic logistics companies are ready to develop and improve. They need little: it is enough to form clear and transparent rules of the game, to adopt laws that would simplify the procedures related to the movement of goods both inside the country and in international trade. It is necessary a clear state strategy for logistics development.

The response to business expectations and awareness of the importance of logistics for economic growth of the state is creation of a logistics committee of the Cabinet of Ministers of Ukraine in January 2017. The committee includes representatives of the World Bank, various ministries and departments, public organizations and business structures. The main goal of creating a new advisory body is acceleration of the reforms of the transport infrastructure of Ukraine, as well as attraction of representatives of business and the expert community to a constant dialogue. Now there is a very important work to improve the regulatory and legal framework necessary for the functioning of the national logistics system, in particular, the project «National Transport Strategy of Ukraine for the period until 2030» is presented.

Changes in the market of logistics services in Ukraine show that the realization of a strong logistical potential can be provided in various ways: radical changes in the quality of the transport infrastructure, the creation of a truly competitive environment in all modes of transport, the introduction of the latest achievements in scientific and technological progress and innovative technologies for network interaction between state bodies and business, the introduction of world standards of logistics services and supply chain management, increase of the levels of national transport and environmental safety.

\section{SWOT analysis of research results}

Strength. The strength of this research is the author's definition of the essence and concept of the logistical potential of the national economy, which makes it possible to focus attention on those key aspects of improvements that allow the strategic goals of the development of the economy to be realized.

Weakness. The weakness is that there is no reliable statistical data on the volume of the logistics services market in Ukraine and the value of the logistic component of the national GDP. The lack of reliable statistical data is not enough to conduct an in-depth analysis and make a reliable assessment of the use of the existing logistical potential of the country and, consequently, to conduct benchmarking with other countries.

Opportunities. The opportunities for further research are related to the introduction of foreign experience in identifying logistics costs at the level of the national economy, which will allow to form a system of key indicators of the effectiveness and efficiency of using logistic potential from the point of view of logistics services for the economy and global supply chains, and develop national standards for reporting in the field of logistics and management of supply chains. Targets for improving Ukraine's position in the rating of logistics efficiency and entry into the TOP-50 countries of the world should be laid in the «National Transport Strategy of Ukraine for the period until 2030». Quality improvement of the transport infrastructure and logistics service, the competence of logistics personnel, the elimination of customs barriers, the development of logistics corridors, the transparency and security of supply chains will help to increase the level of competitiveness and efficiency of the national economy. According to the estimates of international experts, the $10 \%$ increase in transportation costs reduces the volume of trade by $20 \%$. Accordingly, the reduction of logistics costs to the level of European countries (10-12\% of GDP) will provide a significant increase in the competitiveness of domestic goods in international markets. 
Threats. The threats for the conducted research are associated with the fact that the market of logistical services is constantly changing. Underestimation of the role of logistic infrastructure in terms of attracting transit flows of goods and its effective use for interregional cooperation has already led to the loss of a significant transit potential of Ukraine and, accordingly, irrational use of resources. The creation of modern logistics centers in the border with Ukraine (in particular in Hungary, Slovakia, Poland, Turkey, Romania), development of multimodal transport corridors between Asia and Europe, bypassing Ukraine, high value-added export-oriented products (primarily agricultural, the logistic component of the cost of which almost $40 \%$ higher than in Germany and France)) are the challenges to which the government must respond. There is an urgent need to develop a model of the national logistics system, which, by analogy with Finland, China, Singapore, Thailand, Indonesia and other countries, will enable to qualitatively change the existing infrastructure, promote the development of the market of integrated logistics services and the growth of business and the state competencies in the management of the logistic potential.

\section{Conclusions}

1. Analysis of the publications of well-known economists, analytical reviews of macroeconomic indicators and the state of the domestic business environment allows to state that the Ukrainian economy is at an important stage of its development. On the one hand, our state actively joined the world geopolitical and geo-economic processes: joined the World Trade Organization, signed the Association Agreement with the European Union, adapted many national concepts to national conditions, in particular, to simplify trade procedures. On the other hand, in order to stimulate domestic production of goods and services and to replenish the state budget, the government encourages the export of goods and the increase in sales of domestic products in the markets of the European Union, Asia, Africa, and America. These tasks actualize the problem of diagnosing the state and determining the directions of development of the country's logistics potential. The proposed author's understanding of the essence and concept of the logistic potential of the national economy in the form of a four-dimensional model with the system of coordinates «resources-ability-management system-competence», where the resource plane reveals the phenomenon of transforming capabilities into abilities, and abilities through their disclosure, consolidation and renewal through training are transformed into competence. The implementation of a set of such opportunities occurs in the context of business processes and self-organization processes and contributes to the creation of value for stakeholders. The key to achieving these results is development of criteria system for the effectiveness of the logistic activity of business structures and their impact on the use of the country's resource potential, indicators of the efficiency of the logistic system of the national economy and the level of use of logistics potential, as well as strategic benchmarks for quality economic growth.

2. The analysis show that the key positions in the field of geo-economic competition are taken by those countries that perceive logistics as a factor of the global competitiveness of the national economy and pay significant attention to the development of the logistics infrastructure and the logistics services market. Of course, any form of estimating the magnitude and level of use of the country's logistics potential deserves attention, since in the system of analysis, diagnostics or monitoring they allow to operate not only with specific figures, but also serve for the adoption of strategic or tactical managerial decisions. An important condition for development of a capacity assessment system is to minimize the subjectivity that can be achieved through a clear definition of evaluation criteria for basic indicators. It is proved that the indicators of the state of the logistics system should meet the key indicators of the international LPI logistics efficiency rating, which reflect the result of the implementation of the logistics potential. The efficiency of the national logistics system is to be evaluated from the point of view of aggregate logistics costs, which should reflect the quality of the realization of the logistics potential.

3. To increase the efficiency of using the existing logistics potential of Ukraine, it is strategically important to eliminate bottlenecks, which are determined on the basis of international ratings and indicators of the quality of logistics services, and increase the capacity of the existing logistics infrastructure through intensification of logistics processes. A general indicator of the effectiveness of the national logistics system and an indicator of the level of use of logistics capacity is the share of logistics costs in the GDP structure. The total cost of logistics reflects the costs of resources for implementation of logistics operations for servicing goods traffic for various sectors of the economy. On the basis of research, it has been established that the logistic component of GDP is almost $18 \%$. This indicator reflects the sectoral GDP structure and shows significant reduction reserves due to increased productivity of logistics infrastructure, liquidation of customs, information and price barriers, effective state management of the development of the country's logistics system. On the other hand, statistical data on the volume of provided transport, warehouse, postal and courier services, which are identified in the national system for collecting statistical data, can be considered the lower limit of national logistics costs. Now they fluctuate in the range of 6-7\% of GDP, which indicates a low level of logistic outsourcing in the country.

\section{References}

1. Global Logistics Market 2017-2021 [Electronic resource]. Available at: \www/URL: https://www.technavio.com/report/ global-logistics-market-2017-2021

2. Global 3PL Market Size Estimates [Electronic resource] // Armstrong \& Associates. - Available at: \www/URL: http:/ www.3plogistics.com/3pl-market-info-resources/3pl-market-information/global-3pl-market-size-estimates/

3. Havenga, J. H. Logistics Barometer South Africa 2016 [Electronic resource]: Report / J. H. Havenga, Z. P. Simpson, D. King, A. de Bod, M. Braun. - Stellenbosch University, 2016. - Available at: \www/URL: http://www.sun.ac.za/english/ faculty/economy/logistics/Documents/Logistics\%20Barometer/ Logistics\%20Barometer\%202016\%20Report.pdf

4. State of Logistics Indonesia 2013 [Electronic resource]. - Center of Logistics and Supply Chain Studies, 2013. - Available at: \www/URL: http://logistics-center.itb.ac.id/wp-content/ uploads/StateofLogisticsIndonesia2013.pdf

5. Cebeci, C. Analysis of the Logistics Systems in Bulgaria under the Requirements of the European Union [Text] / C. Cebeci, M. Yankova // Research Journal of Applied Sciences, Engineering and Technology. - 2013. - Vol. 6, № 14. - P. 2526-2534. 
6. Rantasila, K. Measuring logistics costs. Designing a generic model for assessing macro logistics costs in a global context with empirical evidence from the manufacturing and trading industries [Electronic resource] / K. Rantasila // Turun kauppakorkeakoulun julkaisuja (väitöskirja). - 2013. - № A-8:2013. - Available at: \www/URL: https://www.doria.fi/handle/10024/93317

7. Arvis, J.-F. Connecting to Compete: Trade Logistics in the Global Economy [Electronic resource] / J.-F. Arvis, D. Saslavsky, L. Ojala, B. Shepherd, C. Busch, A. Raj, T. Naula. - The International Bank for Reconstruction and Development/The World Bank, 2016. - 82 p. - Available at: \www/URL: https:// wb-lpi-media.s3.amazonaws.com/LPI_Report_2016.pdf

8. Zimina, A. I. Priorities for the Development of Logistics Activity of National Economy in the Contemporary Business Environmen [Text] / A. I. Zimina // Business Inform. - 2016. № 2. - P. 88-95.

9. Rodrigues, A. M. Estimation of global and national logistics expenditures: 2002 data update [Text] / A. M. Rodrigues, D. J. Bowersox, R. J. Calantone // Journal of Business Logistics. 2015. - Vol. 26, № 2. - P. 1-16. doi:10.1002/j.2158-1592.2005. tb00202.x

10. Stock, J. R. Strategic Logistics Management [Text] / J. R. Stock, M. D. Lambert. - McGraw-Hill/Irwin, 2001. - 872 p.

11. Protsenko, O. D. The Development of National Competitiveness and the Modern Management [Text] / O. D. Protsenko, I. O. Protsenko // Rossiiskoe predprinimatel'stvo. - 2012 . № 2 (200). - P. 36-42.

12. Poleshchuk, I. I. Otsenka logisticheskogo potentsiala gosudarstva $\mathrm{v}$ usloviiah globaliziruiushcheisia ekonomiki. Logisticheskie sistemy i protsessy v sovremennyh ekonomicheskih usloviiah [Text] / I. I. Poleshchuk, T. Sh. Zorina, P. A. Lavrentiev, E. S. Shershunovich // Materialy Mezhdunarodnoi zaochnoi nauchno-prakticheskoi konferentsii, 1-15 noiabria 2013 g. Minsk: National Library of Belarus, 2013. - P. 135-146.

13. Huliahina, O. S. Economic content of logistic potential of the supply chain [Text] / O. S. Huliahina // Journal of Science and Education of North-West Russia. - 2015. - № 2 (1). P. 245-253.

14. Shostak, L. V. Formation of logistic potential of enterprise [Text] / L. V. Shostak // Visnyk Odeskoho natsionalnoho universytetu. Seriia: Ekonomika. - 2015. - Vol. 20, № 4. P. $151-154$

15. Hurzhii, N. M. The logistic potential of the enterprise es timation as a basis of its logistic strategy choice [Text] N. M. Hurzhii, A. I. Overchenko // Global and National Problems of Economy. - 2016. - № 13. - P. 244-248.

16. Zhavoronkova, H. V. Stratehichne upravlinnia aviatransportnymy pidpryiemstvamy [Text]: Monograph / H. V. Zhavoronkova, I. P. Sadlovska, T. N. Shkoda, V. O. Zhavoronkov; ed. by H. V. Zhavoronkova. - Kyiv: Kondor-Vydavnytstvo, 2012. - 676 p.

17. Koblianska, I. I. Logistic potential of a region: essence and methodical approach to its evaluatiion [Text] / I. I. Koblianska, N. A. Rubalko, O. V. Mishchenko // Visnyk Sumskoho derzhavnoho universytetu. Seriia Ekonomika. - 2015. - № 2. P. 23-30.

18. Smerichevska, S. V. Osvitno-innovatsiinyi potentsial lohistyzatsii ekonomiky i yoho kilkisna otsinka [Text] / S. V. Smerichevska // Menedzher. Visnyk Donetskoho derzhavnoho universytetu upravlinnia. - 2014. - № 1 (67). - P. 246-251.
19. Gritsenko, S. I. Transportno-logisticheskie klastery v Ukraine: puti stanovleniia i razvitiia [Text]: Monograph / S. I. Gritsenko. - St. Petersburg: SPbGUEF, 2009. - 218 p.

20. Perebyinis, V. I. Innovatsiina lohistyka: kontseptsii, modeli, mekhanizmy [Text]: Monograph / V. I. Perebyinis; ed. by M. Yu. Hryhorak, L. V. Savchenko. - Kyiv: Lohos, 2015. - 548 p.

21. Logistics Report 2016 [Electronic resource]. - Freight Transport Association, 2016. - Available at: \www/URL: http://www.fta. co.uk/export/sites/fta/_galleries/downloads/logistics_report/ lr16-web-030616.pdf

22. The Global Competitiveness Report 2016-2017 [Electronic resource] // World Economic Forum. - Available at: \www/ URL: https://www.weforum.org/reports/the-global-competitiveness-report-2016-2017-1

23. Sergeev, V. I. Analiz sushchestvuiushchih mezhdunarodnyh podhodov dlia otsenki effektivnosti logistiki [Text] / V. I. Sergeev, D. I. Zinina // Logistika i upravlenie tsepiami postavok. 2013. - № 2. - P. 4-19.

24. Rantasila, K. National-level logistics costs: an overview of extant research [Text] / K. Rantasila, L. Ojala // International Journal of Logistics Research and Applications. - 2015. - Vol. 18, № 4. - P. 313-324, doi:10.1080/13675567.2015.1016413

25. Slusarczyk, B. Logistics costs identification in SME in Poland [Text] / B. Slusarczyk, S. Kot // Advanced Logistic Systems. - 2013. - Vol. 1, № 7. - P. 91-96

26. Hovi, I. B. Logistics costs in Norway. Key figures and international comparisons [Text] / I. B. Hovi, W. Hansen. - Oslo: Institute of Transport Economics, 2010. - 112 p.

27. Yu, C. The Analysis of the China National Logistics Costs Structure [Text] / C. Yu // Management and Engineering. 2015. - № 21. - P. 77-84.

28. Weng, X. Restudy on Macro Logistics Cost of China [Text] X. Weng, X. Du // Modern Economy. - 2015. - Vol. 06 , № 11. - P. 1173-1179. doi:10.4236/me.2015.611111

\section{СРАВНЕНИЕ ЭКОНОМИЧЕСКИХ ИНДИКАТОРОВ ИСПОЛЬЗОВАНИЯ}

\section{ЛОГИСТИЧЕСКОГО ЛОТЕНЫИАЛА УКРАИНЫ}

Обобщены сущность и определение логистического потенциала национальной экономики, определены ключевые показатели его эффективного использования. Предложено совокупность экономических индикаторов, определяющих уровень использования потенциала логистики на макроуровне. Проведен анализ влияния экономических индикаторов на конкурентоспособность и эффективность национальной экономики с точки зрения ее геоэкономического измерения. Рассчитаны оценочные значения национальных логистикичних расходов и разработаны предложения по усовершенствованию логистической системы Украины в соответствии со стратегическими приоритетами национальной экономики.

Ключевые слова: национальная логистическая система, логистический потенциал национальной экономики, рынок логистических услуг.

Grygorak Mariya, PhD, Associate Professor, Head of the De partment, Department of Logistics, National Aviation University, Kyiv, Ukraine, e-mail: $m$ grigorak@ukr.net, ORCID: http://orcid.org/ 0000-0002-5023-8602 